\title{
Determinants of income inequality reduction in the Latin American countries
}

\author{
Carmen Ramos Carvajal, Mercedes Alvargonzález Rodríguez \\ and Blanca Moreno Cuartas
}

\begin{abstract}
This article analyses patterns of income inequality and its determinants in the countries of Latin America in the period 2004-2013. First, income distribution in several countries is determined using the Theil index and is found to have decreased over the study period. An econometric panel data model is then employed to study the determinants of the level of inequality. Per capita GDP, per capita health spending, tax pressure, the poverty rate, the literacy rate and years of schooling are found to be statistically significant variables in explaining inequality. Multivariate techniques are then used to group the countries by level of inequality, thereby establishing a classification in terms of ability to reduce inequality.
\end{abstract}

\section{Keywords}

Income distribution, equality, measurement, econometric models, factor analysis, Latin America

\section{JEL classification}

C23, O15, 054

\section{Authors}

Carmen Ramos Carvajal is a Professor in the Faculty of Economics and Business of the Department of Applied Economics of the University of Oviedo, Spain. Email: cramos@uniovi.es.

Mercedes Alvargonzález Rodríguez is a Professor in the Faculty of Economics and Business of the Department of Applied Economics of the University of Oviedo, Spain. Email: malvarg@uniovi.es.

Blanca Moreno Cuartas is a Professor in the Faculty of Economics and Business of the Department of Applied Economics of the University of Oviedo, Spain. Email: morenob@uniovi.es. 


\section{Introduction}

One of the most extensively documented characteristics of the Latin American countries is their high levels of inequality in family income distribution. As noted by Gasparini and Gluzmann (2012), most of the region's countries have always been among the most unequal societies of the developed world. Europe and the United States, even in the worst crisis periods, have had and continue to have much lower levels of inequity than Latin America, as discussed in Ayala (2013).

Economic inequality is understood to refer to the fundamental disparity that affords one individual certain material opportunities while denying them to another. On the basis of measures of income distribution inequality, it can be determined how growth and development is distributed between different social groups.

Income distribution is fundamental for determining the dynamics that generate economic growth and well-being of the population. Equitable distribution of income is one of the features of developed societies, whereas less developed economies tend to display more unequal distribution of income and wealth. This is undoubtedly a recurring theme in the literature, given its importance and its implications for well-being.

It may seem natural to assume that inequality would increase in situations of economic crisis. However, a number of studies have shown that the inequality-crisis binomial is not always present and that level of inequality is highly influenced not only by economic circumstances but also by the structure and characteristics of each territory, which precludes a generalized direct two-way link (Atkinson and Morelli, 2011; Adiego and Ayala, 2013).

A variety of conceptual approaches to inequality have been developed. Significant work has been done, among others, by Cowell (1977), Nygard and Sandström (1981), Foster (1983), Zubiri (1985), Ruiz-Castillo (1987), Pena and others (1996) and Dagum (2001).

Other authors have analysed economic and social inequality from a more applied perspective and in relation to Latin America. For example, without claiming to be exhaustive: Ariza and de Oliveira (2007), Martín (2008), Azevedo and others (2013), Lustig, López-Calva and Ortiz-Juárez (2013), Gasparini and Gluzmann (2012), and Morgan and Kelly (2013).

However, despite Latin America's high levels of inequality, analysis of economic development statistics shows that in the first decade of this century the region saw significant economic growth alongside a reduction in inequality. This may be thanks to the application of income transfer policies and investments in health and education (Perticara, 2012).

The main purpose of this work is to analyse patterns of income inequality and determinants of its evolution in Latin America countries in the past few years.

To this end, sections II and III examine inequality in income distribution in the Latin American countries in the period 2004-2013, using one of the most common measures employed for this purpose, the Theil index.

Section IV performs a breakdown of total inequality in the region, in two components: the inequality within each country and inequalities between countries. This exercise serves to analyse which of these components has been most influential in total inequality.

Section V estimates the impact of certain variables - such as GDP, education, health spending, poverty and tax pressure - on the reduction of inequality in the Latin American countries during the study period. A panel data methodology is used to perform this estimation, in order to control for specific unobservable effects in each country. 
To complete this work, section VI uses multivariate techniques such as cluster and factor analyses. Cluster analyses yield groupings of countries that show similar patterns in the variables considered. Meanwhile, factor analysis is used to condense the information into a single indicator that can be used to determine which countries are best positioned to reduce inequality.

Lastly, the conclusions in section VII compile the main findings of the work.

\section{Inequality: measurement and description of evolution}

The literature on inequality offers a very large number of inequality indicators. This article uses the Theil index because of its decomposability, a property of great interest for empirical studies. The Gini index, a commonly used measure, has the limitation of non-decomposability, that is, it cannot be used to obtain the total inequality of a population from the internal inequality of its constituent groups and inequality between groups.

There follows a definition of the Theil index (1967): let $X$ be the variable for income, which takes values $\left\{x_{1}, \ldots, x_{M}\right\}$ with relative sequences $\left\{f_{1}, \ldots, f_{M}\right\} E(X)$ denotes the expected value of $X$, that is, the per capita income of the population. ${ }^{1}$ The Theil index (TI) is given by:

$$
T I(X)=\frac{1}{E(X)} \sum_{i=1}^{M} x_{i}\left[\log \frac{x_{i}}{E(X)}\right] f_{i}=\frac{1}{E(X)} \sum_{i=1}^{M} x_{i}\left[\log \left(x_{i}\right)-\log (E(X))\right] f_{i}
$$

This indicator may be interpreted as the weighted mean of the deviations between the log of income and the log of per capita income of the population.

The main advantage of using a log function is that it permits greater importance to be assigned to the lower incomes, which is appropriate from the normative perspective of inequality as a social problem.

Under equidistribution, individuals' income would coincide with the expected value and the index would be zero, while in the opposite case, where one person accumulated all the income, the upper bound of the index would be given by $M \log (M)$.

The Theil index is an appropriate indicator of inequality, because it has a series of properties that are considered desirable. ${ }^{2}$ These include continuity, symmetry and the Pigou-Dalton principle (that is, if part of a rich person's income is transferred to a poor person, without altering the order of the ranges of income, inequality should not increase). ${ }^{3}$ The Theil index also fulfils the principle of decreasing impact of progressive transfers, i.e. the closer the individuals involved in the progressive transfers are to the lower tail of the distribution, the more the value of the index falls (as long as the transfers are of the same amount and are made between individuals whose income differential is identical). It also fulfils the condition of non-homotheticity i.e. given constant total income, as inequality increases, greater importance is afforded to the situation of poorer individuals.

Lastly, as noted earlier, the Theil index fulfils the property of decomposition. This requires a consistent relationship between the level of total inequality in the population and inequality in its constituent subgroups. If information is available for $M$ countries, the Theil index is given by:

\footnotetext{
1 Theil was the first author to propose measurements of statistical information as a suitable framework for the study of inequality, on the basis of conceptual and operational arguments.

2 Shorrocks (1980) was one of the authors to study the properties of the Theil index.

3 In the strongest form of this property, inequality should decrease.
} 


$$
T I(X)=\sum_{C=1}^{M} T I_{P}(X) \frac{E_{C}(X)}{E(X)} \frac{N_{C}}{N}+\sum_{C=1}^{M} \frac{E_{C}(X)}{E(X)} \frac{N_{C}}{N} \log \left(\frac{E_{C}(X)}{E(X)}\right)
$$

where $\operatorname{TI}_{P}(X)$ is the Theil index for country $C, N_{C}$ is the population of country $C, N$ is the general population, $E(X)$ is total per capital income and $E_{C}(X)$ is the per capita income of country $C$.

The first summand in equation (2) captures the internal inequality of the countries and the second captures the discrepancy between the different countries.

\section{Income inequality in the Latin American countries}

Latin America comprises the countries of the American continent where Romance languages are spoken, such as Spanish and Portuguese, i.e. Mexico, almost all of Central America (Costa Rica, El Salvador, Guatemala, Honduras, Nicaragua and Panama) and almost all the countries of South America (Argentina, Bolivarian Republic of Venezuela, Brazil, Chile, Colombia, Ecuador, Paraguay, Peru, Plurinational State of Bolivia and Uruguay). The rest of the continental countries of Central and South America (Belize, Guyana, Suriname and the territory of French Guiana) are generally not considered part of Latin America, since their cultural and economic ties link them more closely with the Caribbean region. There are Latin-colonized American countries in the Caribbean Sea: Cuba, the Dominican Republic and Puerto Rico, of Hispanic origin and French-colonized Haiti.

The work in this article encompasses 15 continental Latin American countries of those mentioned above, plus the Dominican Republic. It does not include the Bolivarian Republic of Venezuela, Cuba, Honduras or Nicaragua, owing to lack of necessary information. Puerto Rico is not included either, as a United States territory, nor is Haiti, as a country culturally more associated with the Caribbean than with Latin America and because it has a very precarious household survey system. In short, the countries included in this study are: Argentina, Brazil, Chile, Colombia, Costa Rica, Dominican Republic, Ecuador, El Salvador, Guatemala, Mexico, Panama, Paraguay, Peru, Plurinational State of Bolivia and Uruguay.

\section{Reconstruction of a database on inequality: first results}

The Theil index is used to quantify income inequality in Latin America, since it fulfils the properties described above and has been used in a good number of studies (Villaverde, 1996; Duro, 2004; Goerlich and Mas, 2004; Martín, 2008; Azevedo and others, 2013, and Amarante, Galván and Mancero, 2016, among others).

This study covers a 10-year period (from 2004 to 2013), which is considered long enough to conduct a rigorous analysis of income inequality.

The first step was to compile information on inequality in the countries included for the period of the study, which was done using data on the Theil index provided by the World Bank and the Socio-Economic Database for Latin America and the Caribbean (SEDLAC).

Unfortunately, the information from these sources was not complete, and estimates had to be conducted for data that were not available for certain years and countries. Gómez, Palarea and Martín (2006) establish a classification of techniques for data imputation, such as use of the mean, ${ }^{4}$ regression, stochastic regression and other more complex methods based on verisimilitudes. The latter,

4 Imputation of the mean is generally not recommendable, as it shows very unstable behaviour. 
while offering the best alternative, may involve a computation effort that, in certain situations, is not rewarded by the virtues of the inference. The present work employs regression to impute the missing observations, as this method yields good results and is simpler to implement, as noted by Gómez, Palarea and Martín (2006).

Table 1 shows the inequality levels for the countries of Latin America obtained using the Theil index for the period 2004-2013. The values shown with asterisks are the results of estimates. Coefficients of determination were calculated to ascertain the adequacy of the estimates; as may be seen, these are relatively high.

Table 1

Latin America: Theil index of inequality, 2004-2013a

\begin{tabular}{|c|c|c|c|c|c|c|c|c|c|c|c|}
\hline Country & 2004 & 2005 & 2006 & 2007 & 2008 & 2009 & 2010 & 2011 & 2012 & 2013 & Mean \\
\hline Argentina & 0.451 & 0.449 & 0.446 & 0.423 & 0.389 & 0.358 & 0.346 & 0.332 & 0.312 & 0.310 & 0.382 \\
\hline $\begin{array}{l}\text { Bolivia (Plurinational } \\
\text { State of) }\end{array}$ & $0.602^{*}$ & 0.547 & 0.472 & 0.469 & 0.389 & 0.416 & $0.34^{*}$ & 0.277 & 0.297 & 0.309 & 0.397 \\
\hline Brazil & 0.647 & 0.647 & 0.629 & 0.603 & 0.588 & 0.578 & $0.576^{\star}$ & 0.560 & 0.581 & $0.543^{*}$ & 0.604 \\
\hline Chile & $0.607^{*}$ & 0.601 & 0.568 & $0.590^{*}$ & $0.584^{*}$ & 0.585 & $0.572^{*}$ & 0.541 & $0.561^{*}$ & 0.537 & 0.566 \\
\hline Colombia & 0.625 & 0.622 & $0.631^{*}$ & $0.630^{*}$ & 0.632 & 0.614 & 0.627 & 0.599 & 0.568 & 0.574 & 0.608 \\
\hline Costa Rica & 0.411 & 0.399 & 0.427 & 0.466 & 0.427 & 0.474 & 0.455 & 0.481 & 0.481 & 0.487 & 0.451 \\
\hline Dominican Republic & 0.577 & 0.494 & 0.564 & 0.462 & 0.493 & 0.471 & 0.411 & 0.435 & 0.392 & 0.429 & 0.473 \\
\hline Ecuador & 0.605 & 0.584 & 0.747 & 0.622 & 0.512 & 0.481 & 0.491 & 0.399 & 0.430 & 0.440 & 0.531 \\
\hline El Salvador & 0.415 & 0.437 & 0.404 & 0.412 & 0.434 & 0.408 & 0.358 & 0.337 & 0.335 & 0.409 & 0.395 \\
\hline Guatemala & 0.406 & $0.483^{*}$ & 0.550 & $0.608^{*}$ & $0.657^{*}$ & $0.696^{\star}$ & $0.726^{\star}$ & 0.746 & $0.757^{\star}$ & $0.759^{*}$ & 0.567 \\
\hline Mexico & 0.588 & 0.635 & 0.527 & $0.559^{*}$ & 0.599 & $0.529^{*}$ & 0.458 & $0.498^{*}$ & 0.503 & $0.468^{*}$ & 0.552 \\
\hline Panama & $0.534^{*}$ & $0.511^{*}$ & $0.547^{\star}$ & $0.520^{\star}$ & 0.522 & 0.532 & 0.540 & 0.557 & 0.536 & 0.522 & 0.535 \\
\hline Paraguay & 0.630 & 0.560 & 0.724 & 0.665 & 0.570 & 0.505 & 0.636 & 0.589 & 0.484 & 0.464 & 0.583 \\
\hline Peru & 0.508 & 0.522 & 0.519 & 0.516 & 0.451 & 0.432 & 0.403 & 0.387 & 0.376 & 0.367 & 0.448 \\
\hline Uruguay & 0.420 & 0.383 & 0.416 & 0.429 & 0.400 & 0.407 & 0.380 & 0.342 & 0.299 & 0.312 & 0.379 \\
\hline Mean & 0.535 & 0.525 & 0.545 & 0.532 & 0.510 & 0.499 & 0.488 & 0.472 & 0.461 & 0.462 & \\
\hline Typical deviation & 0.088 & 0.082 & 0.102 & 0.082 & 0.088 & 0.088 & 0.116 & 0.124 & 0.125 & 0.115 & \\
\hline
\end{tabular}

Source: Prepared by the authors, on the basis of data from the World Bank and the Socio-Economic Database for Latin America and the Caribbean (SEDLAC).

a The values of the coefficients of determination for each of the countries whose inequality was estimated are: Brazil: 0.81; Chile: 0.60; Colombia: 0.84; Guatemala: 0.97; Mexico: 0.54, Panama: 0.71; and Plurinational State of Bolivia: 0.89.

Generally speaking, it may be said that, on average, the countries with the highest levels of inequality are Brazil, Chile, Colombia, Ecuador, Guatemala, Mexico, Panama and Paraguay. Meanwhile, Argentina, Costa Rica, the Dominican Republic, El Salvador, Peru, the Plurinational State of Bolivia and Uruguay display lower levels of inequality. These results largely coincide with studies by Martín (2008), Amarante, Galván and Mancero (2016), and Amarante and Jiménez (2016), among others.

On the basis of analysis of inequality in the countries over the study period, three groups may be identified. In a first group - made up of Brazil, Chile, Colombia, Mexico and Paraguay - inequality is always above the average. These countries could be described as the most unequal from a structural point of view, since their level of inequity is above average for all the years examined. In a second group of countries - Argentina, El Salvador, Peru and Uruguay - inequality is below the average 
throughout the period; accordingly, these are the least unequal countries structurally speaking. Lastly, a third group - Costa Rica, the Dominican Republic, Ecuador, Guatemala, Panama and the Plurinational State of Bolivia - show an inequality index above the average for some years and below the average for others. In this group of countries, inequality varies depending on economic and social circumstances.

\section{The trend of inequality}

Table 1 shows how total average inequality has decreased over the past few years. Observation of the indexes of inequality for each country for the first and last years of the period analysed shows that only Costa Rica and Guatemala have higher levels of inequality at the end of the period than at the beginning; the other countries show decreases over the period. Between 2004 and 2013 inequality has thus tended to fall. This has been noted by various authors, including Amarante, Galván and Mancero (2016), and Lustig, López-Calva and Ortiz-Juárez (2013). Some authors, however, such as Piketty (2014), indicate that inequality is underestimated in the Latin American countries owing to the concealment of high incomes.

In order to verify whether the differences in the inequality indicators at the beginning and the end of the period are significant, a Wilcoxon test was performed for two samples. The results are shown in table 2.

Table 2

Wilcoxon test, test statistics ${ }^{a}$

\begin{tabular}{lc}
\hline$Z$ & -2.272 \\
\hline Asymptotic significance (bilateral) & 0.023 \\
\hline
\end{tabular}

Source: Prepared by the authors.

a Wilcoxon tests of signed ranges.

The null hypothesis of the Wilcoxon test (that inequality matches in the two periods) is rejected because the critical level is below 0.05; thus, statistically significant differences are found in inequality at the two points in time. At the same time, the Z-statistic demonstrates and bears out the decline in the level of inequality.

In addition, rates of variation in inequality were calculated, taking 2004 at the starting point and 2013 as the end. Given that in general terms inequality varies relatively little from one year to the next, it seems most appropriate to calculate the rate over the whole study period in order to detect changes in this variable. However, since a global economic crisis occurred during this period, the rates for an intermediate point -2007 - were calculated as well, as the point at which the crisis was considered to have broken out. That is, the rates were calculated between 2004 and 2007 (the period before the crisis) and between 2008 and 2013 (the crisis period). The results are shown in table 3.

Observation of the entire study period shows that most of the countries have been able to reduce their levels of inequality, with the exception of Costa Rica and Guatemala. The countries that have reduced inequality the most are the Plurinational State of Bolivia, Argentina, Peru and Ecuador. When the two subperiods are examined, it is seen that the decrease in inequality begins in the first and is not slowed by the crisis; on the contrary, inequality decreases faster, generally speaking. This pattern, noted by Lustig, López-Calva and Ortiz-Juárez (2013) and Cornia (2012 and 2014), among others, indicates that the global crisis did not affect the downtrend in inequality, probably because the crisis affected the Latin American region less than other world regions, as pointed out by Mancha, Perticarari and Buchieri (2011) and Quenan (2013). 
Table 3

Rates of variation in inequality, 2004-2013

(Percentages)

\begin{tabular}{lccc}
\hline Country & $2004-2013$ & $2004-2007$ & 2008-2013 \\
\hline Argentina & -31.33 & -6.12 & -20.41 \\
\hline Bolivia (Plurinational State of) & -48.57 & -22.08 & -20.51 \\
\hline Brazil & -16.04 & -6.84 & -7.58 \\
\hline Chile & -11.53 & -2.87 & -8.02 \\
\hline Colombia & -8.16 & 0.80 & -9.18 \\
\hline Costa Rica & 18.49 & 13.38 & 14.05 \\
\hline Dominican Republic & -25.52 & -19.95 & -12.93 \\
\hline Ecuador & -27.23 & 2.81 & -13.93 \\
\hline El Salvador & -1.49 & -0.75 & -5.73 \\
\hline Guatemala & 86.95 & 49.75 & 15.53 \\
\hline Mexico & -20.41 & -4.93 & -21.87 \\
\hline Panama & -2.25 & -2.62 & 0.00 \\
\hline Paraguay & -26.26 & 5.55 & -18.55 \\
\hline Peru & -27.80 & 1.58 & -18.67 \\
\hline Uruguay & -25.66 & 2.21 & -22.05 \\
\hline
\end{tabular}

Source: Prepared by the authors.

\section{Quantification of the components of inequality in Latin Aamerica}

The Theil index may be used to quantify inequality in an entire region, with the level determined by two aspects: inequality within each country (internal inequality or $I I$ ) and the inequality of one country with respect to the others (inequality between countries or $B I$ ). The application of this property of decomposition permits the weight of both aspects to be ascertained and measured (see Villaverde (1996), Duro (2004), Goerlich and Mas (2004) and Martín (2008), among others). Equation (2) may be broken down into two summands: the first captures internal inequality within countries and the second captures the discrepancy between the different countries, so that total inequality $(T Q)$ is the sum of the two, that is:

$$
T Q=I I+B I
$$

This formulation was applied to the data available to quantify inequality in the entire region made up of the 15 countries studied, then that value was disaggregated into the components of internal inequality and inequality between countries. The results for the period studied are shown in table $4 .^{5}$

\footnotetext{
5 Using data on population and median income provided by the Economic Commission for Latin America and the Caribbean (ECLAC) and the Socio-Economic Database for Latin America and the Caribbean (SEDLAC).
} 
Table 4

Decomposition of inequality obtained using the Theil index, 2004-2013

\begin{tabular}{lccccc}
\hline Year & Internal inequality $(\mathrm{II})$ & $\begin{array}{c}\text { Inequality between } \\
\text { countries }(\mathrm{BI})\end{array}$ & Total inequality (TQ) & $\begin{array}{c}\text { II/TQ } \\
\text { (percentages) }\end{array}$ & $\begin{array}{c}\mathrm{B} / \mathrm{TQ} \\
\text { (percentages) }\end{array}$ \\
\hline 2004 & 0.585 & 0.005 & 0.590 & 99.15 & 0.85 \\
\hline 2005 & 0.595 & 0.005 & 0.599 & 99.21 & 0.79 \\
\hline 2006 & 0.569 & 0.007 & 0.577 & 98.73 & 1.27 \\
\hline 2007 & 0.562 & 0.006 & 0.568 & 98.89 & 1.11 \\
\hline 2008 & 0.555 & 0.004 & 0.559 & 99.34 & 0.66 \\
\hline 2010 & 0.529 & 0.004 & 0.534 & 99.21 & 0.79 \\
\hline 2011 & 0.507 & 0.006 & 0.513 & 98.93 & 1.07 \\
\hline 2013 & 0.502 & 0.005 & 0.507 & 99.07 & 0.93 \\
\hline
\end{tabular}

Source: Prepared by the authors.

Total income inequality for Latin America overall fell between 2004 and 2013, as noted earlier. This fall in inequality is due, above all, to the decrease in internal disparities within the countries, since the inequality between countries held steady over the period studied. It may also be seen that the internal inequality component accounted for a much greater proportion of total inequality than inequality between countries in that period. These results seem to indicate that overall inequality in the region originates not so much in differences between countries, but in inequities within each. These findings are consistent with those of Milanovic and Muñoz (2008), who note that in Latin America as a whole, the differences in mean incomes between countries explain a relatively small part of inequality, while most is accounted for by inequalities within each country.

At the same time, analysing the second summand (BI) in equation (2)

$$
B I=\sum_{C=1}^{15} \frac{E_{C}(X)}{E(X)} \frac{N_{C}}{N} \log \left(\frac{E_{C}(X)}{E(X)}\right)
$$

serves to ascertain which countries generate inequality and which "benefit" from it and which "suffer". If $E C(X)$ is less than $E(X)$-i.e. if a country's expected income is below the expected income for the region, the quotient is less than 1 and the corresponding term is negative - then the country will "suffer" inequality. Conversely, if $E C(X)$ exceeds the total per capita income, the quotient is greater than 1 and the corresponding term is positive, then the country is a generator of inequality and "benefits" from it.

Table 5 presents the values for the different summands of inequality between countries.

The table shows stable patterns over time. Brazil and Colombia, for example, are countries that suffer inequality, since their income is below the mean for the region, while Argentina, the Bolivarian Republic of Venezuela, Chile, Costa Rica, the Dominican Republic, El Salvador, Mexico, Peru and Uruguay are generators of inequality, as their income is above the mean.

Having seen how inequality has decreased in Latin America, there follows an analysis of which determinants may be influencing this evolution. On the basis of the information available, this will be done by econometric analysis of panel data. 
Table 5

Summands of inequality between countries, 2004-2013

\begin{tabular}{lcccccccccc}
\hline Country & 2004 & 2005 & 2006 & 2007 & 2008 & 2009 & 2010 & 2011 & 2012 & 2013 \\
\hline Argentina & 0.005 & 0.008 & 0.011 & 0.012 & 0.012 & 0.013 & 0.013 & 0.015 & 0.016 & 0.016 \\
\hline $\begin{array}{l}\text { Bolivia (Plurinational } \\
\text { State of }\end{array}$ & 0.000 & -0.003 & -0.003 & -0.002 & 0.000 & 0.001 & 0.000 & 0.002 & 0.001 & 0.000 \\
\hline Brazil & -0.039 & -0.036 & -0.029 & -0.029 & -0.027 & -0.029 & -0.034 & -0.031 & -0.028 & -0.031 \\
\hline Chile & 0.003 & 0.003 & 0.003 & 0.003 & 0.002 & 0.001 & 0.001 & 0.001 & 0.001 & 0.001 \\
\hline Colombia & -0.004 & -0.002 & -0.017 & -0.016 & -0.010 & -0.011 & -0.012 & -0.010 & -0.010 & -0.010 \\
\hline Costa Rica & 0.001 & 0.002 & 0.001 & 0.001 & 0.001 & 0.000 & 0.001 & 0.000 & 0.000 & 0.000 \\
\hline Dominican Republic & 0.002 & 0.003 & 0.001 & 0.003 & 0.002 & 0.002 & 0.002 & 0.002 & 0.003 & 0.002 \\
\hline Ecuador & 0.000 & 0.000 & 0.001 & -0.001 & 0.001 & 0.002 & 0.001 & 0.003 & 0.003 & 0.002 \\
\hline El Salvador & 0.003 & 0.002 & 0.004 & 0.004 & 0.002 & 0.002 & 0.002 & 0.003 & 0.003 & 0.003 \\
\hline Guatemala & 0.002 & 0.001 & -0.001 & 0.000 & 0.000 & -0.001 & -0.001 & -0.001 & -0.002 & -0.002 \\
\hline Mexico & 0.028 & 0.023 & 0.033 & 0.026 & 0.014 & 0.018 & 0.024 & 0.013 & 0.008 & 0.014 \\
\hline Panama & -0.001 & 0.000 & -0.001 & 0.000 & 0.000 & 0.000 & 0.000 & 0.000 & -0.001 & 0.000 \\
\hline Paraguay & 0.001 & 0.001 & 0.000 & 0.001 & 0.001 & 0.001 & 0.000 & -0.001 & 0.001 & 0.000 \\
\hline Peru & 0.004 & 0.002 & 0.002 & 0.001 & 0.005 & 0.005 & 0.007 & 0.007 & 0.007 & 0.008 \\
\hline Uruguay & 0.002 & 0.002 & 0.001 & 0.001 & 0.001 & 0.001 & 0.001 & 0.001 & 0.002 & 0.002 \\
\hline Total for the region & 0.005 & 0.005 & 0.007 & 0.006 & 0.004 & 0.004 & 0.006 & 0.005 & 0.005 & 0.005 \\
\hline
\end{tabular}

Source: Prepared by the authors.

\section{Determinants of the evolution of income inequality in Latin American countries, econometric panel data model}

As noted earlier, the problem of inequality in Latin America has been addressed in different works and taking different approaches. Here, panel data methodology is used to explore which variables or factors may be determining the evolution of inequality levels in the period studied.

Among the variables that may determine economic inequality, the literature is unanimous in including the relative magnitudes of economic growth, education, health and the role of public policies, among others.

Table 6 shows the specific variables used in the analysis: per capita GDP, per capita health spending, tax pressure, a poverty indicator, the literacy rate, years of schooling, and an indicator of the effect of the economic crisis.

Panel data methodology was used to estimate the model, since this controlled for unobservable effects in each country.

Public policies act on market-based distribution by means of instruments such as taxes and transfers, which impact directly on the distribution of families' disposable income. Another facet of the State's redistributive action occurs through mechanisms that may be considered indirect, such as spending on education or health care. Although these do not affect households' current disposable income, they do produce a very important impact, albeit deferred, insofar as they foster human capacities, facilitate labour-market integration and contribute to higher standards of living (Amarante and Jiménez, 2016). 
Table 6

Taxonomy of variables used

\begin{tabular}{llll}
\hline & Definition & Unit & Source \\
\hline Theil index & Indicator of income inequality & $0-1$ & $\begin{array}{l}\text { World Bank/Socio-Economic Database for } \\
\text { Latin America and the Caribbean (SEDLAC) }\end{array}$ \\
\hline Per capita GDP & Proxy for country's level of development & $\begin{array}{l}\text { Thousands of dollars } \\
\text { per capita }\end{array}$ & ECLAC \\
\hline Per capita health spending & $\begin{array}{l}\text { Per capita spending on health care } \\
\text { by the public sector }\end{array}$ & $\begin{array}{l}\text { Thousands of dollars } \\
\text { per capita }\end{array}$ & ECLAC \\
\hline Tax pressure & Tax income in relation to GDP & Percentages & ECLAC \\
\hline Years of schooling & $\begin{array}{l}\text { Average years of schooling } \\
\text { of the population aged 25-59 years }\end{array}$ & Years & World Bank / SEDLAC \\
\hline Literacy rate & $\begin{array}{l}\text { Literacy rate of the population } \\
\text { aged 15-24 years }\end{array}$ & Percentages & World Bank / SEDLAC \\
\hline Poverty & Population living in poverty & Percentages & World Bank / SEDLAC \\
\hline Effect of the economic crisis & $\begin{array}{l}\text { Dummy variable (takes a value of 0 in the } \\
\text { period 2004-2007 and 1 in 2008-2013) }\end{array}$ & 0 and 1 & Authors \\
\hline
\end{tabular}

Source: Prepared by the authors.

In this regard, empirical studies have shown that education is a tool that helps to reduce inequity in income distribution (Alonso, 2001; Moller, Alderson and Nielsen, 2009; Peters, 2013, among others).

Authors such as Mercader-Prats and Levy (2004), Atkinson and Brandolini (2009), and Muinelo and Roca (2013) have drawn attention to the role of fiscal policy in explaining inequality. In this regard, the structure of the tax system should play a very important part (Molina, Guarnido and Amate, 2013). Peters (2013) notes that fiscal policy is an endogenous variable that reflects, through political processes, the preferences of the citizens (voters) regarding income distribution.

Levy and Schady (2013) and Azevedo, Inchaust and Sanfelice (2013) indicate a direct relationship between economic inequality and poverty, since both rise and fall following similar patterns.

However, since Kuznets (1955) proposed the well-known "U hypothesis", economic growth has been the factor most studied as an explanatory variable for inequality in income distribution. However, findings on the effects of economic growth on inequality are not unanimous. In the context of Latin America, De Janvry and Sadoulet (2000) and Medina and Galván (2014a and 2014b) have studied relationships between economic growth, inequality and poverty.

\section{Panel data model, econometric specification}

This methodology allows consideration of latent unobservable effects specific to each country (individual effects). If those unobservable effects exist and are not corrected, there will be a problem of omitted variables and the coefficients estimated in the model will be biased (see a detailed description of the panel data methodology in Baltagi, 1995). In addition, to avoid potential omitted variable bias because of variables that change over time, but are constant between countries, the model includes time effects.

$T I(X)_{i t}=\alpha_{i}+\beta_{0}+\beta_{1} G D P p c_{i t}+\beta_{2} H S_{i t}+\beta_{3} P I_{i t}+\beta_{4} T P_{i t}+\beta_{5} L R_{i t}+\beta_{6} Y S_{i t}+\beta_{7} E C_{i t}+u_{i t}$

Where $i$ denotes the countries considered $(i=1, \ldots, 15), t$ are the years $(t=2004, \ldots, 2013), T I$ is the Theil index, GDPpc is per capita GDP, $H S$ is health spending, $Y S$ are years of schooling, $L R$ is the literacy rate, $T P$ is tax pressure, $P I$ is a poverty index and $E C$ is a variable that captures the effect of the crisis, taking a value of 0 from 2004 to 2007 and a value of 1 from 2008 to $2013 .{ }^{6} \alpha_{i}$ represents

\footnotetext{
${ }^{6}$ A crisis is considered to have occurred when GDP growth falls. The reference in this work is to the global crisis of the period 2008-2013.
} 
the specific individual effect of each country, and is included in the model to take into account any factor that could influence the level of inequality beyond the explanatory variables included. Disturbances are denoted by uit and are assumed to be independent and identically distributed, with mean 0 and variance $\sigma_{\mathrm{u}}^{2}$

In order to identify the most appropriate specification of the panel model, the estimate was performed for both a fixed effects and a random effects model. The fixed effects model treats each $\alpha_{i}$ as a constant in the regression, while the random effects model treats $\alpha_{i}$ as a component of random disturbance. A Hausman test (1978) is performed in order to establish whether the random effects estimator is more suitable than the fixed effects one. The existence of specific effects for each country is contrasted using an F-test (for the fixed effects model) or the Breusch-Pagan test (for the random effects model). In both cases, the null hypothesis is that $\alpha_{i}$ is equal for all countries. If that hypothesis is not rejected, then it is a classic regression model and can be estimated by ordinary least squares (OLS). In other words, the Breusch and Pagan test and F-test indicate, respectively, the extent to which the random effects model and the fixed effects model are better than the grouped or merged data model.

Table 7 presents the main descriptive statistics of the variables analysed.

Table 7

Main descriptive statistics of the variables used

\begin{tabular}{lccccc}
\hline Variables & Mean & Median & Minimum & Maximum & Standard deviation \\
\hline Theil index & 0.52 & 0.52 & 0.25 & 0.84 & 0.13 \\
\hline GDPpc & 6.74 & 5.98 & 1.68 & 14.29 & 3.42 \\
\hline Health spending & 0.16 & 0.11 & 0.01 & 0.54 & 0.13 \\
\hline Tax pressure & 13.37 & 13.28 & 8.11 & 20.84 & 3.03 \\
\hline Years of schooling & 8.66 & 8.80 & 4.30 & 11.33 & 1.56 \\
\hline Literacy rate & 97.60 & 98.33 & 84.99 & 99.75 & 2.58 \\
\hline Poverty index & 6.48 & 6.02 & 0.23 & 20.71 & 4.30 \\
\hline
\end{tabular}

Source: Prepared by the authors.

\section{Empirical results}

The results of the final estimations of the panel data model are shown in table 8. A Hausman test was performed and yielded a Chi-squared of $(7)=4.33$ with a critical value of $p=0.7406$, on which basis it is concluded that the random effects model is the most adequate.

The results of the model indicate that the contrasts of individual effects are significant and the Breusch-Pagan test rejects the corresponding null hypothesis on the non-existence of individual effects.

With respect to individual effects (given their existence), the F-statistics of the contrast indicate non-rejection of the null hypothesis (there are no time effects); accordingly, such effects need not be included in the model.

The results shown in table 8 indicate that all the variables, except the effect of the crisis, are significant at $1 \%$. This seems to suggest that the economic crisis had no significant effect in Latin America, at least in relation to the evolution of economic inequality.

The results show a positive relationship with respect to economic development, measured on the basis of GDP, i.e. greater economic development leads to a rise in inequality. This finding is consistent with those obtained by Ravallion and Chen (1997), Molina, Amate and Guarnido (2011), and Acar and Dogruel (2012), for whom economic growth does not reduce income inequalities. Taking per capita GDP as a proxy for economic development, Molina, Amate and Guarnido (2011) find that higher GDP increased inequity in the countries of the European Union. This appears to bear out criticism of the use 
of GDP as a measure of a country's development, since it considers only certain economic aspects and disregards social and environmental behaviours. Thus, an overall rise in a country's GDP may indicate growth, but not necessarily balanced growth (Costanza and others, 2009).

Table 8

Panel data models estimated to explain inequality in Latin American countries, 2004-2013

\begin{tabular}{|c|c|}
\hline Variable & Panel data model \\
\hline \multirow[t]{2}{*}{$\beta_{0}$} & -1.9952 \\
\hline & $(0.009)$ \\
\hline \multirow[t]{2}{*}{$\beta_{1}($ per capita GDP) } & $0.0226^{\star \star \star}$ \\
\hline & $(0.051)$ \\
\hline \multirow{2}{*}{$\beta_{2}$ (per capita health spending) } & $-0.4372^{\star \star \star}$ \\
\hline & $(0.011)$ \\
\hline \multirow{2}{*}{$\beta_{3}$ (poverty) } & $0.0057^{\star \star \star}$ \\
\hline & $(0.096)$ \\
\hline \multirow[t]{2}{*}{$\beta_{4}$ (tax pressure) } & $-0.0169^{\star \star \star}$ \\
\hline & $(0.000)$ \\
\hline \multirow{2}{*}{$\beta_{5}$ (literacy rate) } & $-0.030^{\star \star \star}$ \\
\hline & $(0.000)$ \\
\hline \multirow[t]{2}{*}{$\beta_{6}$ (years of schooling) } & $-0.0546^{\star \star \star}$ \\
\hline & $(0.006)$ \\
\hline \multirow[t]{2}{*}{$\beta_{7}$ (effect of the crisis) } & -0.0138 \\
\hline & 0.329 \\
\hline Observations & 145 \\
\hline $\mathrm{R}^{2}$ & 0.52 \\
\hline \multirow[t]{2}{*}{ Breusch-Pagan test } & $x^{2}(1)=290.18^{\text {*** }}$ \\
\hline & $p \approx 0$ \\
\hline \multirow[t]{2}{*}{ F- F-test } & $F(14.123)=27.23^{\star \star \star}$ \\
\hline & $p \approx 0$ \\
\hline \multirow[t]{2}{*}{ Test de Hausman } & $x^{2}(7)=4.33$ \\
\hline & $p=0.7406$ \\
\hline
\end{tabular}

Source: Prepared by the authors.

Note: ${ }^{* * *}$ means that the null hypothesis was rejected at $1 \%$.

Among the variables that may determine inequality, the literature shows that education is a tool that serves to reduce it (Alonso, 2001; Moller, Alderson and Nielsen, 2009; Peters, 2013, among others); accordingly, literacy and years of schooling exert a redistributive effect (Molina, Guarnido and Amate, 2013). Latin America has considerably increased the basic coverage of education: the percentage of children enrolled in the appropriate grade for their age is over $90 \%$ in primary school and between $60 \%$ and $80 \%$ in secondary school in most of the region's countries (Levy and Schady, 2013).

The effect of tax pressure on income distribution is as expected, as studied by Itriago (2014). However, some authors note that the redistribution capacity of taxes and transfers is limited in terms of changing levels of inequality in households' access to resources (Amarante and Jiménez, 2016), owing to lower levels of tax revenues and lesser distributive impact. Redistributive public spending in Latin America has very often been financed from regressive taxes, which has considerably eroded the net effects of fiscal policy (Gómez Sabaini and Morán, 2013).

Another variable that generates a correction in inequality levels is health spending. Higher health spending leads, indirectly, to lower inequality, by affecting consumption decisions and possibilities, insofar as the availability of good-quality public health services can free up families' resources for other consumption purposes (Gómez Sabaini and Morán, 2013; Atun and others, 2015). In this regard, the coefficient of the variable associated with health has the expected sign. 
The coefficient of the poverty variable is also consistent with the direct correlation that many authors have found with inequality (Levy and Schady, 2013; Azevedo, Inchaust and Sanfelice, 2013). Poverty fell over the period studied, which has probably led to a decline in inequality (Cruces and Gasparini, 2013; Gasparini and Gluzmann, 2012).

It may thus be concluded that the reduction in inequality seen in Latin America is due, at least in part, to a decline in poverty in the countries, as well as attempts to strengthen and expand direct and indirect redistribution policies. ${ }^{7}$

\section{Ranking of Latin American countries by reduction in inequality levels}

Section $V$ determined some of the significant variables that explain, at least in part, the reduction in inequality in Latin America, on the basis of econometric estimations of panel data. These variables and a multivariate classification technique will be used to group the countries under study and determine which are better placed to reduce their levels of inequality.

First, a hierarchical cluster analysis was performed to classify the countries by their disposition to reduce inequality. Ward's method was used to establish the groups, with Euclidean squared distance. This technique is applied to the variables found to be relevant in reducing inequality (per capita GDP, poverty, health spending, years of schooling, literacy rate and tax pressure) for the last year in the period analysed (2013). However, the analysis was repeated for the other years in order to test the robustness of the results obtained, and yielded similar results.

Application of this technique yielded three groupings or clusters (see table 9).

It may appear strange that one of the groupings has only one country, but it was decided to main this three-group structure given the particular idiosyncrasy of Guatemala, which makes this country very different from the others.

The first cluster comprises Argentina, Brazil, Chile, Costa Rica, Mexico, Panama and Uruguay; the second, Colombia, Dominican Republic, Ecuador, Salvador, Paraguay, Peru and Plurinational State of Bolivia; and the third, only Guatemala.

\footnotetext{
7 This work has used the Theil index as an indicator of inequality, on the basis of information from data provided by the World Bank and the Center for Distributive, Labor, and Social Studies (CEDLAS). The Socio-Economic Database for Latin America and the Caribbean (SEDLAC) was used, among other reasons, because it provides information on Argentina, unlike the other databases consulted. This was thought to be important, given Argentina's relative weight in the Latin American economy (in 2015 it represented around 11\% of the GDP of Latin America and the Caribbean). In addition, there are other countries, such as El Salvador, Peru and Plurinational State of Bolivia, for which it is advisable to use World Bank data, given the serious lack of data from other sources. However, ECLAC is also considered to publish a very solid database which qualifies inequality using, among other things, the Theil index (see CEPALSTAT [online] http://estadísticas.cepal.org/cepalstat). By way of illustration, a number of comparisons were conducted between the results produced using both databases to yield a measure of the consistency of the conclusions obtained in this work. Initially, a non-parametric Mann-Whitney-Wilcoxon test was run on the Theil index for each country, to determine whether the behaviour of the two indexes (ECLAC and World Bank) was similar. The result of the test did not reject the null hypothesis (similar behaviour of the indicators from the two statistical sources) with critical levels of over 0.05 for all the countries analysed (except Brazil and the Dominican Republic, for which the hypothesis is rejected). Below, continuing with that comparison, the panel data model is estimated using data from the ECLAC Theil index, finding similar behaviours for the set of variables, with regard to both the signs and the scale of the coefficients. This all seems to indicate that the results are robust for the database employed to quantify inequality indicators.
}

$T I(X)_{i t}=2.689+0.00001 * * G D P p c_{i t}-0.0212^{* *} H S_{i t}+0.0077 P I_{i t}-0.0002^{* *} T P_{i t}-0.0073 * * L R_{i t}-0.1056^{* *} Y S_{i t}-0.0002 E C_{i t}+u_{i t} \quad$ (6)

Where ${ }^{* *}$ indicates that the estimates are significantly different from zero, below the $5 \%$ level. The comparison was not run for the data on poverty - which can also, to a degree, indicate disequilibria in income distribution - because the poverty data reported by ECLAC are taken from the World Bank. 
Table 9

Country groupings by factors in inequality reduction

\begin{tabular}{lll}
\hline Cluster 1 & Cluster 2 & Cluster 3 \\
\hline Argentina & Bolivia (Plurinational State of) & Guatemala \\
\hline Brazil & Colombia & \\
\hline Chile & Ecuador & \\
\hline Costa Rica & El Salvador & \\
\hline Mexico & Paraguay & \\
\hline Panama & Peru & \\
\hline Uruguay & Dominican Republic & \\
\hline
\end{tabular}

Source: Prepared by the authors.

Table 10 characterizes these groups on the basis of the initial variables.

Table 10

Description of the clusters ${ }^{a}$

\begin{tabular}{llrrrr}
\hline & N & Minimum & Maximum & \multicolumn{1}{c}{ Mean } & Standard deviation \\
\hline Poverty & 7 & 0.34 & 6.01 & 2.6329 & 2.09523 \\
\hline Per capita GDP & 7 & 8.75 & 14.29 & 11.4714 & 2.13075 \\
\cline { 2 - 6 } & Health spending & 0.08 & 0.54 & 0.3529 & 0.15892 \\
\cline { 2 - 6 } & Tax pressure & 9.71 & 19.34 & 13.7886 & 3.58807 \\
\cline { 2 - 6 } Years of schooling & 7 & 8.36 & 11.33 & 9.9557 & 1.14490 \\
\hline Literacy rate & 7 & 98.16 & 99.41 & 98.8657 & 0.40435 \\
\hline Poverty & 7 & 2.19 & 7.70 & 4.2443 & 2.02906 \\
\hline Per capita GDP & 7 & 2.23 & 7.06 & 4.7714 & 1.65931 \\
\hline Health spending & 7 & 0.02 & 0.13 & 0.0829 & 0.03450 \\
\hline Tax pressure & 7 & 11.85 & 20.84 & 15.3200 & 2.83287 \\
\hline Years of schooling & 7 & 6.56 & 10.02 & 8.9800 & 1.13561 \\
\hline Literacy rate & 7 & 97.22 & 99.44 & 98.3957 & 0.80027 \\
\hline Poverty & 7 & 14.49 & 14.49 & 14.4900 & - \\
\hline Per capita GDP & 1 & 2.92 & 2.92 & 2.9200 & - \\
\hline Health spending & 1 & 0.03 & 0.03 & .0300 & - \\
\hline Tax pressure & 1 & 10.75 & 10.75 & 10.7500 & - \\
\hline Years of schooling & 1 & 4.82 & 91.90 & 91.9000 & - \\
\hline Literacy rate & 1 & 91.90 & & & \\
\hline
\end{tabular}

Source: Prepared by the authors.

a There is no point in calculating the standard deviation for cluster 3 , since it comprises a single country.

As may be seen in table 10, the first cluster is made up of those countries with lower poverty rates and higher levels of per capita GDP, health spending, literacy and years of schooling, on average. This group of countries may be said to be better positioned to continue reducing inequality levels (solely on the basis of the variables that the analysis showed were relevant). Group 2 consists of countries with higher poverty levels than group 1 and lower values for the other variables analysed, on average. For that reason, these countries are considered to be worse placed than those in the first group to reduce inequality levels. Lastly, Guatemala shows the highest rates of poverty and the lowest rates of per capita GDP, health spending, literacy rate and years of schooling, on average; accordingly, it may be concluded that it is the worst positioned country to reduce inequality (on the basis of the variables studied).

Pursuing this idea, a synthetic indicator was built using multivariate analysis to establish a classification of countries by their position for reducing inequality. This index was calculated for 2013. Although the authors are aware that the number of variables used to build this synthetic indicator is very small, they consider that the analysis is nevertheless an interesting one and sheds light on the phenomenon studied. 
On the basis of Kaiser-Meyer-Olkin (KMO) and Barlett tests, it may be concluded that the data are adequate for a factor model. Table 11 shows that the $\mathrm{KMO}$ text is close to 0.7 and the Barlett test is significant for rejecting the null hypothesis.

Table 11

Kaiser-Meyer-Olkin (KMO) and Barlett tests

\begin{tabular}{llr}
\hline Kaiser-Meyer-Olkin measure & & 0.682 \\
\hline \multirow{3}{*}{ Bartlett test of sphericity } & Approx. Chi-squared & 47.002 \\
\cline { 2 - 3 } & gl & 0.15 \\
\cline { 2 - 3 } & Sig. & 0.000 \\
\hline
\end{tabular}

Source: Prepared by the authors.

From the factor analysis it may be deduced that the variables considered are well explained by the factors retained, since all the communalities are above 0.6 (especially per capita GDP). The communalities are determined by the sum of the coefficients of correlation squared of each variable and the set of factors retained.

$$
h_{j}^{2}(m)=r_{x j, y l}^{2}+\ldots+r_{X j, Y m}^{2}
$$

where $Y i$ represents the $i$-th factor and $X j$ the $j$-th variable, and $m$ is the number of factors extracted (see table 12).

Table 12

Communalities $^{\mathrm{a}}$

\begin{tabular}{lll}
\hline & Initial & Extraction \\
\hline Poverty & 1.000 & 0.753 \\
\hline Per capita GDP & 1.000 & 0.864 \\
\hline Health spending & 1.000 & 0.793 \\
\hline Tax pressure & 1.000 & 0.642 \\
\hline Years of schooling & 1.000 & 0.777 \\
\hline Literacy rate & 1.000 & 0.860 \\
\hline
\end{tabular}

Source: Prepared by the authors.

a The extraction method used is the principal components method.

Table 13 shows that the information contained in the initial variables is condensed into two factors that retain a variance proportion of around $78 \%$.

Table 13

Eigenvalues and proportion of inertia retained

\begin{tabular}{lccc}
\hline \multirow{2}{*}{ Component } & \multicolumn{3}{c}{ Initial eigenvalues } \\
\cline { 2 - 4 } & Total & Percentage variance & Cumulative percentage \\
\hline 1 & 3.483 & 58.051 & 58.051 \\
\hline 2 & 1.206 & 20.098 & 78.148 \\
\hline 3 & 0.730 & 12.158 & 90.307 \\
\hline 5 & 0.328 & 5.460 & 95.767 \\
\hline 6 & 0.163 & 2.723 & 98.490 \\
\hline
\end{tabular}

Source: Prepared by the authors. 
Table 14 shows the matrix of rotated components on the basis of the Varimax method. It may be seen that the first factor is directly correlated with per capita GDP and health spending and inversely correlated with poverty. This axis captures economic factors that are involved in reducing inequality. The second factor is related directly to the literacy rate, years of schooling and taxes, i.e. it represents the impact of fiscal and social (basically education) policies, on reducing inequality.

Table 14

Matrix of rotated components ${ }^{a}$

\begin{tabular}{lcc}
\hline & \multicolumn{1}{c}{ Component } & 2 \\
\cline { 2 - 3 } & \multicolumn{1}{c}{0} & 0.051 \\
\hline Per capita GDP & 0.928 & 0.037 \\
\hline Pealth spending & 0.890 & -0.553 \\
\hline Literacy rate & -0.668 & 0.791 \\
\hline Tax pressure & 0.484 & 0.776 \\
\hline Years of schooling & -0.198 & 0.637 \\
\hline
\end{tabular}

Source: Prepared by the authors.

a Rotation method: Varimax with Kaiser normalization. Rotation converged in three iterations.

The synthetic indicator was prepared by obtaining the factor scores associated with the initial variables (see table 15).

Table 15

Component score coefficient matrix

\begin{tabular}{lcc}
\hline & \multicolumn{2}{c}{ Component } \\
\cline { 2 - 3 } & 1 & 2 \\
\hline Poverty & -0.162 & -0.185 \\
\hline Per capita GDP & 0.436 & -0.232 \\
\hline Health spending & 0.406 & -0.203 \\
\hline Tax pressure & -0.220 & 0.423 \\
\hline Years of schooling & 0.135 & 0.216 \\
\hline Literacy rate & 0.023 & 0.370 \\
\hline
\end{tabular}

Source: Prepared by the authors.

On the basis of these values, the synthetic indicator (SI) was obtained for the year considered, as follows:

$$
S I_{j}=\sum_{i=1}^{r} z_{r j} X_{i j}
$$

where $z_{r j}$ represents the weighted average of the factor scores and $X_{i j}$ the initial variables. The results are shown in table 16.

The results obtained from the construction of the synthetic indicator are consistent with those deriving from the cluster analysis: the countries with the highest scores in the ranking (Chile, Argentina, Uruguay, Panama, Costa Rica, Brazil and Mexico) are those in the first cluster. Those that follow (the Dominican Republic, Peru, Colombia, Paraguay, Ecuador, El Salvador and the Plurinational State of Bolivia) are in the second cluster and Guatemala is last in the ranking and some distance behind the country that precedes it. 
Table 16

Synthetic indicator of inequality positioning

\begin{tabular}{lll}
\hline Country & Indicator & Ranking \\
\hline Chile & 12.235 & 1 \\
\hline Argentina & 12.113 & 2 \\
\hline Uruguay & 11.941 & 3 \\
\hline Panama & 11.129 & 4 \\
\hline Costa Rica & 10.888 & 5 \\
\hline Brazil & 10.871 & 6 \\
\hline Mexico & 10.558 & 7 \\
\hline Dominican Republic & 9.967 & 8 \\
\hline Peru & 9.865 & 9 \\
\hline Colombia & 9.773 & 10 \\
\hline Paraguay & 9.770 & 11 \\
\hline Ecuador & 9.730 & 12 \\
\hline El Salvador & 9.024 & 13 \\
\hline Bolivia (Plurinational State of) & 8.514 & 14 \\
\hline Guatemala & 6.898 & 15 \\
\hline
\end{tabular}

Source: Prepared by the authors.

\section{VII.Conclusions}

This work has studied inequality in the Latin American countries using the Theil index for the period 2004-2013. The Theil index was chosen because of the properties it fulfils, particularly decomposition. The different countries have evolved in a heterogeneous manner in relation to inequality. As may be expected, substantial differences were found between one country and another.

The countries with the greatest income inequality over the study period were Brazil, Chile, Colombia, Mexico and Paraguay. Among the least unequal were Argentina, El Salvador, Peru and Uruguay. In the rest of the countries, inequality varies depending on economic and social circumstances (this is the case of Costa Rica, the Dominican Republic, Ecuador, Guatemala, Panama and the Plurinational State of Bolivia).

It was also found that inequality has fallen in most of the countries, except Costa Rica and Guatemala. The countries where inequality fell most over the period were the Plurinational State of Bolivia, Argentina, Peru and Ecuador.

Overall inequality for Latin American was obtained on the basis of internal inequality in each country and inequality between countries, with a fall being observed between 2005 and 2013.

By observing the sign of the indicator of inequality between countries, it may be determined which nations "suffer" inequality and which "generate" it. Here, Brazil and Colombia were found to suffer inequality every year, since their income was below the overall average. The other countries, meanwhile, benefited from inequality, as their income was above the average.

With a view to studying the socioeconomic determinant variables of inequality, a random effects panel data model was estimated. The following variables were found to be significant in explaining inequality: per capita GDP, per capita health spending, tax pressure, poverty rate, literacy rate and years of schooling. The economic crisis unleashed in 2008, which affected Europe so badly, had no significant effects in Latin America. 
In order to systematize the behaviour of the countries vis-à-vis inequality, a cluster analysis was performed using a hierarchical cluster algorithm. The following three clusters were obtained: one comprising the countries with low levels of inequality, another comprising countries with high levels of inequality and third consisting only of Guatemala. The groups are fairly stable and vary little in their composition, which seems to indicate that inequality is a markedly structural characteristic.

Lastly, a synthetic indicator was constructed using factor analysis, to establish a classification of countries by their position in relation to reducing inequality levels.

\section{Bibliography}

Acar, S. and F. Dogruel (2012), "Sources of inequality in selected MENA countries", Structural Change and Economic Dynamics, vol. 23, No. 3, Amsterdam, Elsevier.

Adiego, M. and L. Ayala (2013), "La estructura de la desigualdad de la renta en el largo plazo", Revista de Economía Aplicada, vol. 21, No. 62, Zaragoza.

Alonso, A. (2001), "Logistic regression and world income distribution", International Advances in Economic Research, vol. 7, No. 2, Springer.

Amarante,V., M. Galván and X. Mancero (2016), "Inequality in Latin America: a global measurement", CEPAL Review, No. 118 (LC/G.2676-P), Santiago, Economic Commission for Latin America and the Caribbean (ECLAC).

Amarante. V. and J. P. Jiménez (2016), "Distribución del ingreso e imposición a las altas rentas en América Latina”, Cuadernos de Economía, vol. 35, No. 67, Bogota, National University of Colombia.

Ariza, M. and O. de Oliveira (2007), "Familias, pobreza y desigualdad social en Latinoamérica: una mirada comparativa", Estudios Demográficos y Urbanos, vol. 22, No. 1, Mexico City, El Colegio de México.

Atkinson, A. B. and A. Brandolini (2009), "The panel-of-countries approach to explaining income inequality: an interdisciplinary research agenda", Mobility and Inequality: Frontiers of Research in Sociology and Economics, S. L. Morgan, D. B. Grusky and G. S. Fields (eds.), Stanford, Stanford University Press.

Atkinson, A. B. and S. Morelli (2011), "Economic crisis and inequality", Human Development Research Paper, No. 2011/06, United Nations Development Programme (UNDP).

Atun, R. and others (2014), "Health-system reform and universal health coverage in Latin America", The Lancet, vol. 385, No. 9974.

Ayala, L. (2013), "Crisis económica y distribución de la renta: una perspectiva comparada", Papeles de Economía Española, No. 135, Madrid, Funcas.

Azevedo, J. P., G. Inchaust and V. Sanfelice (2013b), "Decomposing the recent inequality decline in Latin America", Policy Research Working Paper, No. 6715, Washington, D.C., World Bank.

Azevedo, J. P. and others (2013), "Fifteen years of inequality in Latin America: how have labor markets helped?", Policy Research Working Paper, No. 6384, Washington, D.C., World Bank.

Baltagi, B. H. (1995), Econometric Analysis of Panel Data, New York, John Wiley \& Sons.

CEPALSTAT (Databases and Statistical Publications) [online] http://estadisticas.cepal.org/cepalstat/portada. html?idioma=english.

Cornia, G. A. (2014), "Income inequality in Latin America: recent decline and prospects for its further reduction", Macroeconomics of Development series, No. 149 (LC/L.3847), Santiago, Economic Commission for Latin America and the Caribbean (ECLAC).

(2012), "Inequality trends and their determinants. Latin America over 1990-2010", Working Paper, No. 2012/09, United Nations University.

Costanza, R. and others (2009), "Beyond GDP: the need for new measures of progress", The Pardee Papers, No. 4, Boston, Boston University.

Cowell, F. A. (1977), Measuring Inequality, Oxford, Philip Allan Publishers.

Cruces, G. and L. Gasparini (2013), "Políticas sociales para la reducción de la desigualdad y la pobreza en América Latina y el Caribe. Diagnóstico, propuesta y proyecciones en base a la experiencia reciente", CEDLAS Working Papers, No. 0142, La Plata, Center for Distributive, Labor, and Social Studies (CEDLAS) of the National University of La Plata. 
Dagum, C. (2001), "Desigualdad del rédito y bienestar social, descomposición, distancia direccional y distancia métrica entre distribuciones", Estudios de Economía Aplicada, vol. 17, No. 1, International Association of Applied Economics.

De Janvry, A. and E. Sadoulet (2000), "Growth, poverty, and inequality in Latin America: a causal analysis, 1970-94", Review of Income and Wealth, vol. 46, No. 3, Wiley, September.

Duro, J. A. (2004), "La descomposición de la desigualdad de renta per cápita por factores multiplicativos a través del índice de Theil: una revisión metodológica e ilustración para las provincias españolas", Revista de Estudios Regionales, No. 70, Malaga, University of Malaga.

Foster, J. E. (1983), "An axiomatic characterization of the Theil measure of income inequality", Journal of Economic Theory, vol. 31, No. 1, Amsterdam, Elsevier.

Gasparini, L. and P. Gluzmann (2012), "Estimating income poverty and inequality from the Gallup World Poll”, Journal of Income Distribution, vol. 21, No. 1, Toronto, York University.

Goerlich, F. J. and M. Mas (2004), "Distribución personal de la renta en España (1973-2001)", Papeles de Economía Española, vol. 1, No. 100, Madrid, Funcas.

Gómez, J., J. Palarea and J. A. Martín (2006), "Métodos de inferencia estadística con datos faltantes. Estudio de simulación sobre los efectos en las estimaciones", Estadística Española, vol. 48, No. 162, Madrid, National Institute of Statistics.

Gómez Sabaini, J. C. and D. Morán (2014), "Tax policy in Latin America: assessment and guidelines for a second generation of reforms", Macroeconomics of Development series, No. 133 (LC/G.3632), Santiago, Economic Commission for Latin America and the Caribbean (ECLAC).

Hausman, J. A. (1978), "Specification tests in econometrics", Econometrica, vol. 46, No. 6, New York, The Econometric Society.

Itriago, D. (2014), "Política fiscal y desarrollo en América Latina y Caribe", Economía Exterior, No. 70.

Kuznets, S. (1955), "Economic growth and income inequality", The American Economic Review, vol. 45, No. 1, Nashville, Tennessee, American Economic Association.

Levy, S. and N. Schady (2013), "Latin America's social policy challenge: education, social insurance, redistribution”, Journal of Economic Perspectives, vol. 27, No. 2, Nashville, Tennessee, American Economic Association.

Lustig, N., L. F. López-Calva and E. Ortiz-Juárez (2013), "Declining inequality in Latin America in the 2000s: the cases of Argentina, Brazil, and Mexico", World Development, vol. 44, Amsterdam, Elsevier.

Mancha, T., N. Perticarari and F. Buchieri (2011), "Impactos de la crisis financiera en América Latina: principales consideraciones para una discusión”, Working Paper, No. 02/2011, Madrid, University of Alcalá.

Martín, F. (2008), "Evolución de las disparidades espaciales en América Latina. 1950-2008”, Principios. Estudios de Economía Política, No. 11, Madrid, Fundación Sistema.

Medina, F. and M. Galván (2014a), "Crecimiento económico, pobreza y distribución del ingreso. Fundamentos teóricos y evidencia empírica para América Latina, 1997-2007”, Statistical Studies series, No. 82 (LC/L.3689), Santiago, Economic Commission for Latin America and the Caribbean (ECLAC). (2014b), "Sensibilidad de los índices de pobreza a los cambios en el ingreso y la desigualdad. Lecciones para el diseño de políticas en América Latina, 1997-2008”, Statistical Studies series, No. 87 (LC/L.3823), Santiago, Economic Commission for Latin America and the Caribbean (ECLAC).

Mercader-Prats, M. and H. Levy (2004), "The role of tax and transfers in reducing personal income inequality in Europe's regions: evidence from EUROMOD", EUROMOD Working Paper Series, No. EM9/04, Essex, University of Essex.

Milanovic, B. and R. Muñoz (2008), "La desigualdad de la distribución de la renta en América Latina: situación, evolución y factores explicativos”, América Latina Hoy, vol. 48.

Molina, A., I. Amate and A. Guarnido (2011), "Economic and institutional determinants in fiscal pressure: an application to the European case", Journal of Economic Issues, vol. 45, No. 3, Taylor \& Francis.

Molina, A., A. Guarnido and I. Amate (2013), "Los efectos redistributivos del gasto público en la Unión Europea", extoikos, No. 9, Instituto Econospérides.

Moller, S., A. Alderson and F. Nielsen (2009), "Changing patterns of income inequality in U.S. counties, 1970-2000”, American Journal of Sociology, vol. 114, No. 4, Chicago, The University of Chicago Press.

Morgan, J. and N. Kelly (2013), "Market inequality and redistribution in Latin America and the Caribbean", The Journal of Politics, vol. 75, No. 3, Chicago, The University of Chicago Press.

Muinelo, L. and O. Roca (2013), "Joint determinants of fiscal policy, income inequality and economic growth", Economic Modelling, vol. 30, Amsterdam, Elsevier.

Nygard, F. and A. Sandström (1981), Measuring Income Inequality, Stockholm, Almqvist \& Wiksell. 
Pena, J. B. and others (1996), Distribución personal de la renta en España, Madrid, Ediciones Pirámide.

Perticara, M. (2012), "Introducción", Pobreza, desigualdad de oportunidades y políticas públicas en América Latina, Rio de Janeiro, Konrad Adenauer Foundation.

Peters, D. J. (2013), "American income inequality across economic and geographic space, 1970-2010", Social Science Research, vol. 42, No. 6, Amsterdam, Elsevier.

Piketty, T. (2014), Capital in the Twenty-First Century, Cambridge, Massachusetts, Belknap Press.

Quenan, C. (2013), "América Latina frente a la crisis económica internacional: buena resistencia global y diversidad de situaciones nacionales", IdeAs, No. 4, Vanves, Institut des Amériques.

Ravallion, M. and S. Chen (1997), "What can new survey data tell us about recent changes in distribution and poverty?", The World Bank Economic Review, vol. 11, No. 2, Washington, D.C., World Bank.

Ruiz-Castillo, J. (1987), "La medición de la pobreza y la desigualdad en España, 1980-81", Estudios Económicos, No. 42, Bank of Spain.

SEDLAC (Socio-Economic Database for Latin America and the Caribbean) [online] http://sedlac.econo. unlp.edu.ar/.

Shorrocks, A. F. (1980), "The class of additively decomposable inequality measures", Econometrica, vol. 48, No. 3, New York, The Econometric Society.

Theil, H. (1967), Economics and Information Theory, Amsterdam, North Holland Publishing.

Villaverde, J. (1996), "Desigualdades provinciales en España, 1955-1991", Revista de Estudios Regionales, No. 45, Malaga, University of Malaga.

World Bank, "World Bank Open Data" [online] https://data.worldbank.org/.

Zubiri, I. (1985), "Una introducción al problema de la medición de la desigualdad”, Hacienda Pública Española, No. 95, Madrid, Institute for Fiscal Studies. 